\title{
Telaah Fungsi Makna Logis Pada Cerita Rakyat Timun Emas dan Terjemahannya
}

\author{
Dimas Adika \\ Indonesia untuk Anak Sekolah Indonesia (INOVASI), An Aus Aid by Palladium, Indonesia \\ dimasadika@yahoo.com
}

\begin{tabular}{l} 
Article Info \\
\hline Article history: \\
Submitted August 1, 2017 \\
Revised September 20, 2017 \\
Accepted January 26, 2018 \\
Published November 21, 2018
\end{tabular}

\section{Keywords:}

Logical meaning

Folklores

Translation

Text Structure

\begin{abstract}
This article discusses the function of logical meaning which can be identified from logico-semantic and taxis interdependence. This descriptive-qualitative research employs systemic functional linguistics approach. The data sources are all clause complexes in the Timun Emas folkflore written by the best IKAPI writer and translated into English by the translator of Litte Serambi. The function of logical meaning (projection, enhancement and extension) in source and target language spreads to all text structures, started from orientation, complication, evaluation, resolution and coda. The complication had distinctive feature of projection showed by dialogues between characters. Temporal series in the enhancement (time) plays pivotal role in constructing events. Then, the the extension function in Timun Emas folklore and its translation is worthwhile to give information for the comprehensible narrative with the help of chronological series from enhancement (time) function. Next, some changes of the logical meaning after translation process do not seemingly influence to the text structure of this folklore.
\end{abstract}

\section{Corresponding Author:}

Dimas Adika,

Indonesia untuk Anak Sekolah Indonesia (INOVASI)- The Innovation for Indonesia's School Children An Us Aid by Palladium, Indonesia

East Java, Indonesia.

Email: dimasadika@yahoo.com

\section{PENDAHULUAN}

Indonesia kaya akan cerita rakyat. Ia hadir dalam masyarakat dan diturunkan kepada penerus selanjutnya. Menurut Alaini dan Lestariningsih (2014) cerita rakyat merupakan prosa rakyat yang sarat dengan simbol-simbol sistem kebudayaan, pengetahuan, nilai dan cara pandang terhadap dunianya masyarakat pemiliknya. Tentu, cerita rakyat mempunyai nilai lebih dari sekedar bacaan penghibur karena cerita rakyat banyak memiliki khazanah nilai, moral, pandangan hidup dan kesadaran akan budaya. Sejalan dengan itu, Danandjaya (2007) menambahkan bahwa cerita rakyat juga berfungsi sebagai alat pendidik, pelipur lara, protes sosial, dan proyeksi keinginan terpendam.

Kini, cerita rakyat makin banyak dinikmati pembaca berbagai kalangan, sehingga penerjemahan cerita rakyat seperti Timun Emas, Jaka Tarub dan Roro Jonggrang mulai dilakukan (Adika, 2017; Adika 2012:5). Namun, Djatmika dkk (2012:8) mendapati bahwa di Indonesia jumlah karya terjemahan teks narasi yang ditulis penulis atau penerjemah Indonesia masih sedikit jumlahnya. Pada target pembaca anak-anak, masih sering ditemukan terjemahan yang kurang baik dan harus mempertimbangkan umur dan kecakapan bahasa Inggris yang dimiliki. Terlepas dari itu semua, usaha penerjemah dan 
penerbit di Indonesia dalam menerjemahkan cerita rakyat bahasa Indonesia ke dalam bahasa Inggris patut diberi apresiasi. Tersebab utamanya adalah telah memperkenalkan ragam budaya Indonesia kepada dunia melalui cerita rakyat Indonesia.

Dilihat dari unsur pembangunnya, cerita rakyat terdiri atas banyak klausa kompleks. Klausa kompleks adalah klausa yang mengandung lebih dari satu proses utama. Sebaliknya, klausa simpleks hanya memiliki sebuah proses atau setara dengan kalimat sederhana. Kerumitan klausa kompleks mempengaruhi proses penerjemahan dan terjemahan yang dihasilkan. Nababan (2008: 73) mencatatkan klausa kompleks lebih sulit dipahami daripada kalimat sederhana. Dalam hal ini, penerjemah mesti berhati-hati bahwa klausa kompleks memiliki kerumitan makna logisnya. Halliday \&Matthiessen (2004:445) menambahkan bahwa makna logis tersebut direalisasikan dalam hubungan semantik logis dan ketergantungan klausa.

Secara sederhana, makna logis tampak dari perwujudan konjungsi internal dan eksternal dalam merajut pemahaman pembaca atas kejadian yang ada dalam teks cerita rakyat. Adika (2017) menuliskan bahwa hubungan ketergantungan atau interdependensi menunjukkan tingkat ketergantungan klausa kompleks secara setara (parataktik) ataukah tidak setara (hipotaksis). Sebaliknya, hubungan logiko semantik merupakan hubungan perluasan makna yang bersifat modifying melalui pengembangan semantik antar klausa subordinasinya atau klausa yang sejajar (Santosa, 2003:94-95). Perluasan makna ini ditunjukkan melalui hubungan pengalaman antar klausa baik melalui ekspansi; elaborasi $(=)$, ekstensi (+), dan ganda (x) maupun proyeksi; lokusi dan ide. Fungsi-fungsi logis tersebut terdapat dalam bahasa sumber (BSu) dan bahasa sasaran (BSa). Tugas penerjemah dalam hal ini adalah mengalihkan pesan fungsi logis teks BSu ke BSa secara tepat. Dua contoh klausa kompleks dengan fungsi logis dan terjemahannya adalah sebagai berikut,

BSu: “Aku Buto Ijo,” jawab raksasa itu, masih dengan suara yang lantang.

BSa: "I'm Buto Ijo," the ogre said.

Data di atas adalah jawaban dari pertanyaan Mbok Sirni setelah melamun menginginkan seorang anak. Kemudian, tiba-tiba Buto Ijo datang. Data ini memiliki dua fungsi logis dalam BSu. Pertama, sebagai proyeksi lokusi parataksis dari klausa terproyeksi dalam kutipan dan pemroyeksi pada jawab raksasa itu. Kedua, sebagai elaborasi hipotaksis yang berupa klarifikasi pada masih dengan suara lantang. Namun, terjemahan yang dihasilkan menghapus fungsi makna elaborasi hipotaksis tersebut. Contoh kedua,

\section{BSu: Mbok Sirni mencoba mencecohnya, namun sia-sia}

\section{BSa: Mbok Sirni tried to stop him, but to no use}

Data kedua berupa keterangan saat Buto Ijo berusaha mengambil Timun Emas dari Mbok Sirni setelah Timun Emas dewasa. Data ini memiliki fungsi makna logis sebagai ekstensi parataksis. Baik BSu maupun BSa telah membawa fungsi makna logis ini dengan baik. Konjungsi yang tampak untuk mengidentifikasi fungsi logis dalam klausa kompleks ini pada namun, diikuti terjemahannya menjadi but. Ekstensi berarti menambahkan makna baru yaitu setelah mencecohnya, kemudian tidak berhasil dan sia-sia.

Lebih mendalam, kesemua fungsi makna logis yang diperhatikan penerjemah saat menerjemahkan teks adalah tersebar pada seluruh bagian teks cerita rakyat yang merupakan teks narasi. Teks narasi memiliki struktur skematika tersendiri. Bagianbagiannya adalah orientasi, komplikasi, evaluasi dan resolusi (Santosa, 2009:12). Unsurunsur skematika teks narasi di atas berlangsung secara berurutan (chronological order) 
dan bisa hadir terulang kembali. Fungsi makna logis tampaknya memberikan karakteristik tersendiri pada setiap bagian teks narasi BSu maupun BSa.

\section{TEORI DAN METODOLOGI}

\section{Makna Logis Klausa Kompleks}

Eggins (1994:105) dalam Setia (2008) menyebut makna logis sebagai hubungan konjungtif atau pola kohesif konjungsi. Setia menambahkan bahwa jenis hubungan yang dapat ditandai di antara klausa adalah cukup banyak. Secara garis besar, perbedaan jenis hubungan tersebut oleh Halliday \& Matthhiessen (2004: 363) dibagi menjadi dua; ekspansi dan proyeksi.

Kesemua hubungan makna logis ekspansi dan proyeksi memiliki ketergantungan klausa masing-masing baik parataksis maupun hipotaksis. Ekspansi menunjukkan bahwa klausa kedua ( 2 atau $\beta$ ) memperluas makna klausa pertama ( 1 atau $\alpha$ ) dengan beberapa cara (Thompson, 2004:203). Mereka adalah elaborasi (elaboration), ekstensi (extension) dan ganda (enhancement). Elaborasi berarti klausa kedua ( 2 atau $\beta$ ) menyatakan kembali makna klausa pertama ( 1 atau $\alpha$ ) dengan menggunakan cara lain. Kemudian, ekstensi ialah klausa kedua ( 2 atau $\beta$ ) menambah makna klausa pertama (1 atau $\alpha$ ). Terakhir, ganda berarti makna klausa kedua ( 2 atau $\beta$ ) melipatgandakan makna klausa pertama ( 1 atau $\alpha$ ).

Ekspansi jenis pertama adalah elaborasi. Eggins (2004:279) menuliskan bahwa dalam elaborasi, satu klausa mengelaborasi makna klausa lainnya dengan menspesifikasinnya dan mendeskripsikanya. Hal ini dilakukan dengan tiga cara; eksposisi, eksemplifikasi dan klarifikasi. Halliday \& Mattihessen (2004: 397) mengilustrasikan tiga jenis elaborasi sebagai berikut; (i) eksposisi 'dengan kata lain' $\rightarrow$ P adalah Q; (ii) eksemplifikasi 'contohnya' $\rightarrow$ P contohnya Q; dan (iii) klarifikasi 'tepat' $\rightarrow$ P yaitu/yakni Q.

Ekspansi berikutnya yaitu ekstensi. Halliday \& Matthiessen (2004:405) menjelaskan bahwa dalam eksttensi, satu klausa memperluas makna klausa lainnya dengan menambahkan sesuatu yang baru di dalamnya. Penambahan yang dimaksud hanya sebuah tambahan, penggatian, atau sebuah pilihan. Halliday dan Matthiessen kemudian mengilustrasikan ekstensi sebagai berikut; (i) Adisi; Adisi positif 'X dan Y', Adisi negatif 'tidak $X$ dan tidak Y', Adversatif ' $X$ dan kebalikannya $Y$ '. (ii) Variasi; Penggantian 'Tidak X tetapi Y, Subtraktif 'X tetapi tidak semua X'. (iii) Alternasi, X atau Y.

Jenis ekspansi yang terakhir adalah ganda. Ganda memiliki kategori yang sangat banyak dibandingkan ekstensi dan elaborasi. Halliday \& Matthiessen (2004:422) mengelompokkan ganda menjadi lima bagian besar; (i) temporal (same time and different time), (ii) spatial (same place), (iii) manner (means and comparison), (iv) causal-conditional (cause:reason, cause:purpose, cause:result, condition: positive, condition: negative, condition: concessive).

Fungsi logis selanjutnya terwujud dalam logiko semantik berupa proyeksi. Proyeksi merupakan hubungan makna logis yang menunjukkan satu klausa muncul bukan berfungsi sebagai representasi langsung pengalaman linguistik tetapi representasi dari representasi linguistik (Halliday \& Matthiessen, 2004:441). Selanjutnya, Thompson (1996:200) dalam Adika (2017) mengatakan proyeksi (sama seperti kalimat langsung dalam tatabahasa tradisional tetapi dari perspektif yang berbeda); satu kalusa memproyeksikan klausa yang lain dengan pengertian bahwa klausa tersebut menyatakan klausa yang lain adalah susunan kedua penggunaan bahasa, yakni dalam bentuk aslinya, apa yang dikatakan dalam klausa terproyeksi (projected clause) sudah dikatakan di tempat lain. Secara modenya, proyeksi terbagi menjadi proyeksi ide dan proyeksi lokusi. 
Proyeksi ide menggunakan verba mental, sementara itu proyeksi lokusi dengan verba lokusi pada klausa pemroyeksinya.

Keseluruhan fungsi makna logis baik ekspansi maupun proyeksi terdapat dalam seluruh unsur skematika teks narasi. Bagian tertentu diasumsikan memiliki karakateristik makna logis yang khas. Orientasi merupakan struktur yang berisi pengenalan latar cerita berkaitan dengan waktu, ruang, dan suasana terjadinya peristiwa dalam cerita rakyat. Kemudian, komplikasi berisi urutan kejadian, tetapi setiap kejadian itu hanya dihubungkan secara sebab akibat. Menurut Maryanto dkk (2014:19) dalam komplikasi berbagai kerumitan muncul. Untuk mencapai sebuah selesaian atau leraian, diperlukan resolusi. Pada tahapan resolusi ini, konflik yang terjadi diarahkan pada pemecahannya, sebelum masuk ke tahap evaluasi.

\section{Metode Penelitian}

Penelitian ini merupakan penelitian dengan pendekatan kualitatif. Catatan penelitian ditekankan pada pemberian deskripsi kalimat yang rinci, lengkap dan mendalam yang menggambarkan situasi sebenarnya untuk penyajian data (Sutopo: 2006). Lokasi penelitian terletak pada salah satu cerita rakyat Indonesia dwibahasa terbitan Little Serambi, yakni Timun Emas yang ditulis oleh salah satu penulis terbaik Ikatan Penulis Indonesia (IKAPI), Ali Muakhir. Sumber data dalam penelitian ini berupa klausa kompleks teks narasi cerita Timun Emas beserta terjemahannya. Teknik pengambilan data ditempuh melalui analisis dokumen. Analisis dokumen adalah untuk menelaah fungsi makna logis pada klausa kompleks cerita rakyat Timun Emas.

\section{HASIL DAN PEMBAHASAN}

\section{Fungsi Makna Logis Cerita Rakyat Dwibahasa Timun Emas}

Fungsi logis ekstensi parataksis bagian penambahan mendominasi kategori ekstensi. Kategori ini antara satu klausa dengan klausa lainnya diberikan konjungsi 'dan'. Penambahan ini bermaksud untuk memberi informasi baru pada cerita timun emas. Jenis ekstensi terdapat pada seluruh bagian teks narasi baik di orientasi, komplikasi, evaluasi, resolusi maupun koda. Selanjutnya, pada kategri elaborasi, bagian elaborasi hipotaksis klarifikasi muncul lebih sering dibanding jenis elaborasi laiinya. Setia (2008:5) mencatatkan bahwa dalam klarifikasi, klausa kedua mengklarifikasi tesis klausa pertama, mendukung dengan komentar yang sifatnya penjelasan.Jumlah elaborasi pada cerita rakyat ini sangat sedikit dan hanya terdapat pada beberapa bagian teks narasi.

Fungsi makna logis berikutnya berupa ganda. Ganda berarti melipatgandakan makna klausa pertama. Fungsi ganda yang terbanyak berupa ganda hipotaksis (waktu). Rangkaian temporal memerankan peranan yang penting dalam konstruksi kejadian dalam teks naratif. Dengan kata lain, kronologi merupakan bagian kategorisasi yang penting (Halliday, 2004:411). Ganda parataksis terdapat pada seluruh bagian teks, kecuali resolusi. Sementara itu, ganda hipotaksis dijumpai pada semua bagian teks narasi kecuali koda.

Pada bagian proyeksi, jenis proyeksi lokusi parataksis sangat banyak ditemukan terutama pada bagian komplikasi. Hampir seluruh proyeksi lokusi parataksis tersebar di komplikasi. Adika (2017) menuliskan bahwa banyaknya proyeksi jenis lokusi parataktik karena teks narasi cenderung menghendaki banyaknya dialog antar tokoh yang disampaikan dengan mode langsung (parataksis). Mode langsung ini adalah seperti kalimat langsung dalam tata bahasa tradisional. Kemudian, menurut Najim \& Tawfiq 
(2015), teks narasi yang dipenuhi proyeksi lokusi parataktik akan membantu penulis membuat dan menyelesaikan cerita yang ada.

Terdapat beberapa perubahan taksis dalam fungsi makna logis cerita rakyat dwibahasa Timun Emas. Banyaknya hubungan parataksis yang dalam tata bahasa tradisional disebut kalimat langsung adalah karena teks yang dikaji ini merupakan teks narasi cerita rakyat. Teks cerita rakyat Indonesia khas dengan dialog-dialog yang ada di dalamya. Kemudian, mode parataksis membuat pembaca segera mengetahui isi cerita dan sesuai dengan tujuan teks narasi untuk menghibur pembaca.

Tabel 1. Fungsi Makna Logis pada Cerita Rakyat Dwibahasa Timun Emas

\begin{tabular}{|c|c|c|c|c|c|c|}
\hline No & BSu & Jml & $\%$ & BSa` & Jml & $\%$ \\
\hline \multirow[t]{3}{*}{1.} & Ekstensi & & & & & \\
\hline & $\begin{array}{l}\text { Ekstensi Parataksis } \\
\text { (Adisi) }\end{array}$ & 7 & 8,97 & $\begin{array}{l}\text { Ekstensi Parataksis } \\
\text { (Adisi) }\end{array}$ & 7 & 8,97 \\
\hline & $\begin{array}{l}\text { Ekstensi Parataksis } \\
\text { (kontras) }\end{array}$ & 4 & 5,12 & $\begin{array}{l}\text { Ekstensi Parataksis } \\
\text { (kontras) }\end{array}$ & 4 & 5,12 \\
\hline \multicolumn{2}{|r|}{ Jumlah } & 11 & 14,10 & & 11 & 14,10 \\
\hline \multirow[t]{6}{*}{2.} & Elaborasi & & & & & \\
\hline & $\begin{array}{l}\text { Elab. Hipotaksis } \\
\text { (Eksposisi) }\end{array}$ & 1 & 1,28 & $\begin{array}{l}\text { Elab. Hipotaksis } \\
\text { (Eksposisi) }\end{array}$ & 1 & 1,28 \\
\hline & $\begin{array}{l}\text { Elab. } \\
\text { Hipotaksis(Adversatif) }\end{array}$ & 1 & 1,28 & $\begin{array}{l}\text { Elab. Hipotaksis } \\
\text { (Adversatif) }\end{array}$ & 1 & 1,28 \\
\hline & $\begin{array}{l}\text { Elab. Hipotaksis } \\
\text { (Klarifikasi) }\end{array}$ & 3 & 3,84 & $\begin{array}{l}\text { Elab. Hipotaksis } \\
\text { (Klarifikasi) }\end{array}$ & 1 & 1,28 \\
\hline & $\begin{array}{l}\text { Elab. Parataksis } \\
\text { (Eksposisi) }\end{array}$ & 1 & 1,28 & $\begin{array}{l}\text { Elab. Parataksis } \\
\text { (Eksposisi) }\end{array}$ & 1 & 1,28 \\
\hline & Jumlah & 6 & 7,69 & & 4 & 5,12 \\
\hline \multirow[t]{7}{*}{3.} & Ganda & & & & & \\
\hline & Ganda Hipotaksis (tujuan) & 3 & 3,84 & $\begin{array}{l}\text { Ganda Hipotaksis } \\
\text { (tujuan) }\end{array}$ & 3 & 3,84 \\
\hline & Ganda Hipotaksis (waktu) & 18 & 23,07 & $\begin{array}{l}\text { Ganda Hipotaksis } \\
\text { (waktu) }\end{array}$ & 19 & 24,36 \\
\hline & $\begin{array}{l}\text { Ganda Parataksis } \\
\text { (kondisi) }\end{array}$ & 2 & 2,56 & $\begin{array}{l}\text { Ganda Parataksis } \\
\text { (kondisi) }\end{array}$ & 2 & 2,56 \\
\hline & $\begin{array}{l}\text { Ganda Parataksis } \\
\text { (tujuan) }\end{array}$ & 2 & 2,56 & $\begin{array}{l}\text { Ganda Parataksis } \\
\text { (tujuan) }\end{array}$ & 2 & 2,56 \\
\hline & $\begin{array}{l}\text { Ganda Parataksis (Sebab - } \\
\text { Akibat) }\end{array}$ & 1 & 1,28 & $\begin{array}{l}\text { Ganda Parataksis } \\
\text { (Sebab Akibat) }\end{array}$ & 1 & 1,28 \\
\hline & Ganda Parataksis (waktu) & 1 & 1,28 & $\begin{array}{l}\text { Ganda Parataksis } \\
\text { (waktu) }\end{array}$ & 1 & 1,28 \\
\hline & Jumlah & 27 & 34,61 & & 28 & 35,89 \\
\hline \multirow[t]{2}{*}{4.} & Proyeksi Ide & & & & & \\
\hline & Proyeksi Ide Parataksis & 1 & 1,28 & Proyeksi Ide Parataksis & 0 & 0 \\
\hline \multicolumn{2}{|c|}{ Jumlah } & 1 & 1,28 & & $\mathbf{0}$ & $\mathbf{0}$ \\
\hline \multirow[t]{3}{*}{5.} & Proyeksi Lokusi & & & & & \\
\hline & $\begin{array}{l}\text { Proyeksi Lokusi } \\
\text { Hipotaksis }\end{array}$ & 2 & 2,56 & $\begin{array}{l}\text { Proyeksi Lokusi } \\
\text { Hipotaksis }\end{array}$ & 2 & 2,56 \\
\hline & $\begin{array}{l}\text { Proyeksi Lokusi } \\
\text { Parataksis }\end{array}$ & 31 & 39,74 & $\begin{array}{l}\text { Proyeksi Lokusi } \\
\text { Parataksis }\end{array}$ & 32 & 41,02 \\
\hline & Jumlah & 33 & 42,30 & & 34 & 43,58 \\
\hline \multicolumn{2}{|c|}{ Total Seluruh Klausa Kompleks } & 78 & 100 & & 78 & 100 \\
\hline
\end{tabular}


Tabel 2. Persebaran Fungsi Makna Logis pada Terjemahan Cerita Rakyat Timun Emas

\begin{tabular}{|c|c|c|c|c|c|c|c|c|}
\hline \multirow{3}{*}{ No. } & \multicolumn{3}{|c|}{ Fungsi Logis } & \multirow{2}{*}{\multicolumn{5}{|c|}{ Struktur Teks }} \\
\hline & \multirow{2}{*}{\multicolumn{2}{|c|}{$\begin{array}{c}\text { Logiko } \\
\text { Semantik }\end{array}$}} & \multirow{2}{*}{ Taksis } & & & & & \\
\hline & & & & Orien. & Kompl. & Eval. & Reso. & Koda \\
\hline \multirow{6}{*}{1.} & \multirow{6}{*}{ 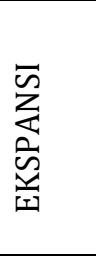 } & \multirow{2}{*}{ Elaborasi } & Parataksis & - & 1 & - & - & - \\
\hline & & & Hipotaksis & - & 2 & - & 1 & 1 \\
\hline & & \multirow{2}{*}{ Ekstensi } & Parataksis & 1 & 6 & 1 & 1 & 1 \\
\hline & & & Hipotaksis & 1 & 1 & - & - & - \\
\hline & & \multirow{2}{*}{ Ganda } & Parataksis & 2 & 2 & 1 & - & 1 \\
\hline & & & Hipotaksis & 2 & 8 & 6 & 5 & - \\
\hline \multirow{4}{*}{2.} & \multirow{4}{*}{ 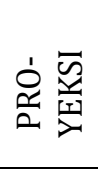 } & \multirow{2}{*}{$\begin{array}{l}\text { Proyeksi } \\
\text { Lokusi } \\
\end{array}$} & Parataksis & 1 & 21 & 4 & 6 & - \\
\hline & & & Hipotaksis & - & - & 1 & - & - \\
\hline & & \multirow{2}{*}{$\begin{array}{l}\text { Proyeksi } \\
\text { Ide }\end{array}$} & Parataksis & - & - & 1 & - & - \\
\hline & & & Hipotaksis & - & - & - & - & - \\
\hline \multicolumn{4}{|c|}{ Jumlah } & 7 & 41 & 14 & 13 & 3 \\
\hline \multicolumn{4}{|c|}{ Total } & \multicolumn{5}{|c|}{78} \\
\hline
\end{tabular}

\section{Semantik Logika; Ekspansi}

Fungsi makna logis klausa kompleks berupa ekspansi baik secara parataksis maupun hipotaksis lebih banyak dijumpai daripada fungsi proyeksi. Hampir keseluruhan ekspansi yang ada memiliki hubungan logis yang sama di bahasa sumber dan bahasa sasaran. Berikut contoh pada setiap kategori besar ekspansi; elaborasi, ekstensi dan ganda. Contoh pertama (1) adalah sebagai berikut,

BSu: ||| Buto Ijo kembali berteriak, || kali ini tidak sekencang sebelumnya |||

$\alpha$ $=\beta$

BSa: ||| Buto Ijo screamed one more time, || his voice already weaker than before. ||| $\alpha$ $=\beta$

Contoh 1 tersebut berada pada bagian resolusi. Resolusi adalah dimana sang tokoh utama mendapatkan ide unutk memecahkan masalah yang berada dalam komplikasi. Ide pemecahan masalah berasal dari titipan ajaib seorang sakti agar melemparkannya ke Buto Ijo. Setelah beberapa kali lemparan, Buto Ijo berteriak, lama-lama teriakannya tidak sekencang sebelumnya dan akhirnya Buto Ijo mati.

Contoh 1 memiliki hubungan elaborasi dengan tingkatan klausanya yang tidak setara (hipotaksis). Elaborasi hipotaksis merupakan suatu strategi untuk memperkenalkan latar belakang informasi dan karakterisasi dari klausa yang dominan. Klausa yang dominan pada contoh tersebut adalah 'Buto Ijo screamed one more time'. Pada klausa selanjutnya, his voice already weaker than before. merupakan komentar klarifikasi yang timbul karena klausa utama.

Konteks sebelumnya, Buto Ijo ingin mengambil Timun Emas karena telah menjadi kesepakatan dengan ibu Timun Emas (Mbok Sirni) saat pertama kali memberikan bibit pohon timun. Mbok Sirni terpaksa menerima tawaran Buto Ijo karena lama tidak memiliki anak. Contoh 2 menegaskan keadaan Mbok Sirni sebelum bertemu Buto Ijo dan termasuk dalam bagian orientasi cerita.

BSu: ||| Suaminya sudah lama meninggal || dan dia tidak dikaruniai seorang anak pun.||| 
BSa: ||| Her husband had long passed away || and she had no children. |||

1

Ekstensi di atas memiliki hubungan taksis yang setara (parataksis) dan memiliki tipe penambahan; positif. Penanda jenis ekstensi penambahan tampak pada diksi 'dan' berikut terjemahannya 'and'. Ekstensi di sini menambahkan makna baru dari klausa kedua. Informasi makna pertama diperoleh dari 'her husband had long passed away' dan informasi makna kedua berasal dari 'and she had no children'. Dalam contoh 3 ini, she mengacu kepada Mbok Sirni. Contoh selanjutnya adalah sebagai berikut.

BSu: ||| Ketika Timun Emas enam tahun,// Buto Ijo datang untukmengambilnya. |||

$$
\mathrm{x} \beta \quad \alpha
$$

BSa: ||| When Timun Emas was six, || Buto Ijo came for take her |||

$$
\mathrm{x} \beta \quad \alpha
$$

Contoh 3 merupakan awal bagian komplikasi atau konflik dimana Mbok Sirni harus menyerahkan Timun Emas yang berusia enam tahun kepada Buto Ijo. Contoh ini memiliki fungsi logis ganda yang melipatgandakan makna dengan hubungan taksisnya yang tidak setara (hipotaksis). Konjungsi yang menjadi penanda dalam hubungan ganda ini adalah 'ketika' yang dalam BSa diterjemahkan menjadi 'when'.

\section{Semantik Logika; Proyeksi}

Adika (2017:5) mencatatkan bahwa proyeksi merupakan perwujudan kembali representasi pengalaman linguistik dalam sebuah klausa. Proyeksi terbagi menjadi dua; proyeksi lokusi dan ide. Proyeksi lokusi menggunakan verba lokusi, sementara proyeksi ide menggunakan verba mental. Hampir keseluruhan proyeksi menggunakan verba lokusi sehingga kemunculan proyeksi lokusi sangatlah tinggi. Hal ini sesuai dengan tujuan teks narasi untuk menceritakan dan menghibur pembaca. Tentu, dalam proses penceritaan banyak digunakan diksi verba lokusi seperti 'berkata', bertanya', 'bergumam', 'berteriak' dan lain-lain. Salah satu contoh proyeksi ada pada contoh 4 berikut.

BSu: ||| “Kamu baik-baik saja, Nak?” || tanya Mbok Sirni. |||

1 "2

BSa: ||| Are you okay, dear?" || asked Mbok Sirni |||

1 "2

Proyeksi di atas terdapat dalam bagian resolusi. Resolusi adalah bagian di mana terdapat pemecahan masalah untuk meredakan komplikasi. Pemecahan masalah muncul saat Timun Emas teringat untuk menaburkan bungkusan ajaib dari seorang petapa suci ke Buto Ijo. Setelah melemparkan bungkusan, Buto Ijo lama-lama tenggelam. Kemudian, Timun Emas segera kembali ke rumah dan saat di rumah Ibunya menanyakan keadaan Timun Emas seperti tertulis pada proyeksi di atas.

Proyeksi di atas termasuk dalam jenis proyeksi lokusi dengan tingkat ketergantungan klausanya yang setara (parataksis). Penanda verba lokusi dalam proyeksi tersebut terdapat pada diksi 'tanya' yang diterjemahkan menjadi 'asked'. Dalam proyeksi, terdapat klausa terproyeksi dan klausa pemroyeksi. Klausa terproyeksi merupakan klausa yang diproyeksikan, dimulai dari "kamu baik-baik saja, Nak?" yang diterjemahkan menjadi "are you okay, dear?". Sementara itu klausa pemroyeksinya adalah 'tanya Mbok Sirni' yang 
diterjemahkan menjadi 'asked Mbok Sirni'. Terakhir, proyeksi jenis ide akan diberikan contohnya pada bagian di bawah ini karena proyeksi ide yang ada mengalami perubahan jenis proyeksi setelah diterjemahkan ke dalam bahasa Inggris.

\section{Perubahan Fungsi Makna Logis}

Halliday \& Matthiessen (2004:445) mencatatkan bahwa fungsi makna logis direalisasikan dalam hubungan semantik logis dan ketergantungan klausa. Dari 65 klausa kompleks, terdapat empat klausa yang di dalamnya memiliki perubahan fungsi makna logis karena diterjemahkan dari bahasa Indonesia ke bahasa Inggris. Terjemahan yang baik tentunya tetap membawa pesan, budaya dan gaya bahasa pada BSu untuk disampaikan pada BSa. Keempat klausa kompleks yang mengalami perubahan fungsi makna logis adalah pada tabel 3 berikut

Tabel 3. Perubahan Fungsi Makna Logis

\begin{tabular}{c|l|l|l|l}
\hline & $\begin{array}{c}\text { Jenis Fungsi } \\
\text { Logis }\end{array}$ & \multicolumn{1}{|c|}{ BSu } & $\begin{array}{c}\text { Jenis } \\
\text { Fungsi } \\
\text { Logis }\end{array}$ & \multicolumn{1}{|c}{ BSa } \\
\hline a & $\begin{array}{l}\text { Proyeksi lokusi } \\
\text { parataksis dan } \\
\text { elaborasi } \\
\text { hipotaksis } \\
\text { (klarifikasi) }\end{array}$ & $\begin{array}{l}\text { "Aku Buto Ijo," jawab } \\
\text { raksasa itu, masih dengan } \\
\text { suara yang lantang. }\end{array}$ & $\begin{array}{l}\text { Proyeksi } \\
\text { Parataksis }\end{array}$ & "I'm Buto Ijo" the ogre said. \\
\hline $\mathrm{b}$ & $\begin{array}{l}\text { Elaborasi } \\
\text { parataksis } \\
\text { (klarifikasi) }\end{array}$ & $\begin{array}{l}\text { Timun Emas sama sekali } \\
\text { tidak menyangka, } \\
\text { ternyata daratan tempat } \\
\text { garam itu tertumpah } \\
\text { berubah jadi lautan yang } \\
\text { dalam. }\end{array}$ & $\begin{array}{l}\text { Ganda } \\
\text { Hipotaksis } \\
\text { tempat } \\
\text { abstrak) }\end{array}$ & $\begin{array}{l}\text { Beyond Timun Emas's the ground which the } \\
\text { salt touched turned into a } \\
\text { deep sea }\end{array}$ \\
\hline $\mathrm{c}$ & $\begin{array}{l}\text { Elaborasi } \\
\text { hipotaksis } \\
\text { (Klarifikasi) }\end{array}$ & $\begin{array}{l}\text { Matahari pagi diam-diam } \\
\text { mengintip Mbok Sirni } \\
\text {,yang sedang mengambil } \\
\text { air dari pancuran. }\end{array}$ & $\begin{array}{l}\text { Ganda } \\
\text { hipotaksis } \\
\text { (Waktu) }\end{array}$ & $\begin{array}{l}\text { The morning sun came up } \\
\text { and greeted Mbok Sirni as } \\
\text { she was fetching water } \\
\text { from The fountain. }\end{array}$ \\
\hline $\mathrm{d}$ & $\begin{array}{l}\text { Proyeksi Ide } \\
\text { Parataksis }\end{array}$ & $\begin{array}{l}\text { "Mudah-mudahan apa } \\
\text { yang dikatakan Buto Ijo } \\
\text { benar," harap Mbok Sirni }\end{array}$ & $\begin{array}{l}\text { Proyeksi } \\
\text { Lokusi } \\
\text { Parataksis }\end{array}$ & $\begin{array}{l}\text { "I hope Buto Ijo wasn't just } \\
\text { making fun of me," said } \\
\text { Mbok Sirni anxiously. }\end{array}$ \\
\hline
\end{tabular}

Klausa kompleks (a) teridentifikasi dalam jenis proyeksi parataksis. Di dalam klausa kompleks tersebut terdapat fungsi elaborasi hipotaksis yang berupa klarifikasi. Elaborasi hipotaksisnya berada pada klausa pemroyeksi, 'Masih dengan suara lantang' merupakan komentar tambahan atau klarifikasi dari klausa sebelumnya 'jawab raksasa itu'. Namun, saat melihat terjemahan yang dihasilkan, penerjemah menghilangkan klarifikasi tersebut, sehingga klausa pemroyeksinya hanya pada 'the ogre said'. Bentuk lokusi parataksis BSu pada klausa a adalah tetap diterjemahkan menjadi klausa parataksis di BSa.

Klausa berikutnya pada BSu masih tergolong pada elaborasi dengan hubungan antar klausanya yang setara (parataksis). Elaborasi parataksis pada klausa (b) berfungsi juga sebagai klarifikasi atau komentar tambahan. Saat diterjemahkan ke dalam BSa, terjadi perubahan fungsi makna logis dari elaborasi parataksis (klarifikasi) menjadi ganda hipotaksis (tempat abstrak) antara the ground which the salt touched turned into a deep sea dan Beyond Timun Emas's belief. Salah satu klausanya lebih superior dari pada lainnya. Tempat abstrak berada pada 'belief' Timun Emas. Selanjutnya, pada klausa kompleks (b), 
klausa yang menjadi superior tersebut masih merupakan klausa kompleks yang bisa dipecah klausanya. Hubungan klausa dalam klausa superior tersebut adalah elaborasi hipotaksis sebagai klarifikasi memberikan tambahan penjelasan terhadap 'the ground' yang dimaksud.

Klausa kompleks (c) berada memiliki hubungan logis elaborasi dengan ketergantungan klausa yang hipotaksis dan berfungsi sebagai klarifikasi. Klarifikasi di sini adalah sebagai komentar tambahan untuk memberi penjelasan terhadap aktifitas yang sedang dilakukan Mbok Sirni. Namun, terjemahan yang dihasilkan memiliki hubungan logis yang berbeda dengan BSu. Penanda elaborasi hipotaksis klausa (c) adalah 'yang', diterjemahkan menjadi ' $a s$ '. Melihat konteks klausa (c), ' $a s$ ' bermakna ketika. Maka, hubungan logis yang muncul menjadi ganda dengan ketergantungan antar klausanya bersifat hipotaksis. Saran terjemahan terhadap klausa kompleks (c) agar tetap membawa makna hubungan logis antar klausa BSunya adalah mengganti 'as she was fetching" dengan "who was fetching".

Terakhir, perubahan terjadi pada klausa kompleks (d) sebagai proyeksi ide parataksis yang menjadi proyeksi lokusi parataksis. Memiliki hubungan parataksis karena masingmasing klausa baik terproyeksi maupun pemroyeksi mampu berdiri sendiri. Penanda diksi yang menggolongkannya menjadi proyeksi ide parataksis terlihat dari kata 'harap' yang berupa proses mental. Setelah diterjemahkan, 'harap' menjadi 'said' yang merupakan proses verbal. Perubahan ini menjadikan terjemahannya tergolong ke dalam proyeksi lokusi parataksis. Penerjemah sebaiknya tetap membawa proses mental dari BSu ke dalam BSa.

\section{SIMPULAN}

Penulis cerita rakyat Timun Emas menggunakan seluruh fungsi makna logis pada seluruh klausa kompleks yang ditulis. Pada bagian ekspansi, penulis menggunakan elaborasi, ekstensi dan ganda. Begitu pula pada proyeksi, ide dan lokusi lengkap digunakan. Hampir seluruh fungsi makna logis tersebut diterjemahkan sesuai kategori fungsi makna logisnya. Hanya beberapa yang mengalami perubahan kategori setelah diterjemahkan oleh penerjemah. Fungsi proyeksi, ganda dan ekstensi pada BSu dan BSa terdapat pada seluruh bagian struktur teks, dimulai dari orientasi, komplikasi, evaluasi, resolusi dan koda. Pada bagian komplikasi, lebih didominasi fungsi proyeksi berupa proyeksi lokusi parataksis yang berupa dialog antar tokoh. Teks narasi cenderung menghendaki banyaknya dialog antar tokoh yang disampaikan dengan mode langsung (parataktik) dan proses verbal (lokusi). Selanjutnya, fungsi ganda hipotaksis berupa waktu banyak dijumpai. Rangkaian temporal memerankan peranan yang penting dalam konstruksi kejadian dalam teks naratif. Terakhir, kemunculan fungsi enhasi bermanfaat untuk memberikan informasi agar pembaca mudah memahami cerita dengan bantuan rangkaian peristiwa secara kronologis melalui fungsi ganda baik pada BSu maupun BSa. 


\section{DAFTAR PUSTAKA}

Alaini, N.N \& Lestariningsih, D.N. (2014). Cerita Rakyat sebagai Referensi Pembelajaran BIPA, Teknik Pengajaran Bahasa Indonesia melalui Cerita Rakyat Putri Mandalika. Asile 2014 Conference, 29 - 30 September 2014.

Adika, D. (2012). The translation analysis of cultural words in the novel the land of five towers. Unpublished Thesis: University of Jambi

Adika, D. (2017). Kajian terjemahan klausa kompleks proyeksi pada cerita-cerita rakyat nusantara dwibahasa di Indonesia. International Conference on Language anda Literature UMS, 2 - 4 April 2017.

Dananjaya, J. (1997). Folklor Indonesia. Jakarta: Pustaka Utama Grafiti.

Djatmika, Khrisna, \& Nuraeni. (2014). Systemic Strategies to Improve the Readability of English Version of Indonesia Children Stories. Jurnal Kata ISSN 2302-6294 (Online): Petra.ac.id.

Eggins, S. (2004). An introduction to systemic functional linguistics. Second edition. London: Continuum.

Halliday, M.A.K \& Matthiessen, C. (2004). An introduction to functional grammar. Edisi ketiga. London: Hodder Arnold.

Maryanto, Indriastuti, A.M, Wahyuni, D, \& Hayati, N. (2014). Bahasa Indonesia ekspresi diri dan akademik (BSE). Jakarta; Pusat Kurikulum dan Perbukuan Balitbang Kemdikbud.

Nababan, M.R. (2008). Teori menerjemah bahasa Inggris. Cetakan III. Yogyakarta: Pustaka Pelajar.

Najim, H.K \& Tawfiq, M.N. (2015). Projection in Arabic Narrative Texts: A Systemic Perspective. International journal of English language, Literature and Humanities. Volume III Issue VII September 2015.

Santosa, R. (2003). Semiotika sosial. Surabaya: Pustaka Eureka dan JP Press.

Santosa, R. (2009). Genre in Media Discourse. Article in Journal of Bahasa, Sastra dan Studi Amerika, English Department; Universitas Sebelas Maret.

Setia, E. (2008). Klausa Kompleks dan Variannya. Jurnal Ilmiah Bahasa dan Sastra 'Logat', Volume IV No. 1 April Tahun 2008

Sutopo. (2002). Metodologi penelitian kualitatif. Surakarta: Universitas Sebelas Maret Press.

Thompson, G. (2004). Introducing functional grammar. Second Edition. London: Edward Arnold. 